(C) 1992 ISIJ

|IIIIIIIIIIIIIIII

論 文

|IIIIIIIIIIIIIII!

\title{
コークス充填層における溶融スラグの静的 ホールドアップの支配因子
}

\author{
大楠 洋* ·佐々 豊**富田 幸雄 ${ }^{*}$ \\ 田中 勝博* ${ }^{*}$ 長谷川守弘 ${ }^{* 2}$
}

Main Factors Affecting Static Holdup of Molten Slag in Coke-packed Bed

\author{
Hiroshi Ohgusu, Yutaka Sassa, Yukio Tomita, \\ Katuhiro TANAKA and Morihiro Hasegawa
}

\begin{abstract}
Synopsis :
Fundamental experiments under high temperature were carried out to clarify the dropping behavior and residual mechanism of molten slag in the lower part of blast furnace.

According to the result of experiment, it was verified that residual phenomenon of molten slag in the coke-packed bed was controlled by capillarity caused by immersion wetting. Static holdup of molten slag was able to be shown by dimensionless empirical formula considering balance between static pressure and that based on immersion work.

Void diameter affected the quantity of slag droplet that residued in graphite funnel, that is to say, the quasi-packed bed, and its residue was present only under critical void diameter. It is estimated that static holdup indicates almost zero under the condition that coke diameter in the deadman is more than about 20 $\mathrm{mm}$.

Key words : static holdup; blast furnace; capillarity ; measurement ; deadman ; fundamental experiment ; immersion wetting; molten slag; packed bed.
\end{abstract}

\section{1. 緒言}

高炉滴下帯での溶銑やスラグ等, 融液のホールドアッ プが増加すると, 充塡層の見かけの空隙率を減少させ, 通気性や炉芯への伝熱に悪影響をおよぼすと考えられて いる. すなわち, 融液のホールドアップはガスの圧力損 失や融液の炉内滞留時間を定める際に不可欠な基礎デー 夕であり, 高炉の生産限界等の操業解析を行うためには, このホールドアップの推定が必要である。

充塡層内での液ホールドアップは大別すると, 静的 ホールドアップと動的ホールドアップに分類できるが, いずれも粒子の充填構造, 融液の物性や充填物との濡れ 性にその量は依存すると考えられている ${ }^{1)}$. 福武ら ${ }^{1)}$, あるいは杉山ら ${ }^{2)}$ は滴下帯と力学的に相似な条件で冷間 模型実験を行い，その結果に基づき，液ホールドアップ の推算式を提案している. しかし、これまでの水溶液を 用いた冷間模型による研究では物性值 (特に, 表面張力)
や充填物との需れ性が溶銑やスラグとは大幅に異なり， 溶銑やスラグのホールドアップについて，そのメカニズ ムは十分に検討されたとはいいがたい。一方，高温条件 下での調査では，佐藤ら ${ }^{3)}$ が黒鉛製漏斗をコークス充填 層と想定し，X 線透過装㯰を備えた電気炉を用いて溶 銑の滴下挙動の直線観祭を行っている．また，丹羽ら ${ }^{4)}$ は羽ロサンプラーを用いて炉内容物を採取し, 溶銑, ス ラグの静的ホールドアップとコークス調和平均径との関 係を調查している.

本研究は, 高炉滴下带でのスラグの滞留メカニズム, すなわち, 静的ホールドアップの支配因子を明らかにす るため, 佐藤ら ${ }^{3)}$ と同様の模擬充塡層, ならびにコーク ス充塤層に高炉系スラグを滴下できる滴下带シミュレー 夕でガス流れのない条件での静的ホールドアップの測定 を行い，その測定值を別途実測した密度，表面張力や黒 鉛との接触角を用いて解析した。また，実炉コークス充 壃層の通液性を把握するため, 静的に融液が滞留する限 
界コークス径について検討を加えた。

\section{2. 実 験 方 法}

\section{$2 \cdot 1$ 模擬充填層によるスラグ融液の滴下実験}

Fig. 1 に実験装置の概略を示す。装置は二珪化モリ ブデン $\left(\mathrm{MoSi}_{2}\right)$ 電気炉，模擬充塡層としての黑鉛製漏 斗，スラグ捕集るつぼから構成されている．黑鉛製漏斗 は内径 $40 \mathrm{~mm}$ であり，底部に $122^{\circ}$ の傾斜を設けた。

供試スラグは特級試薬の $\mathrm{SiO}_{2}, \mathrm{Ca}(\mathrm{OH})_{2}, \mathrm{Al}_{2} \mathrm{O}_{3}$, $\mathrm{MgO}$ を配合し，黒鉛るつぼで溶解後に粉砕したもので ある. 実験パラメーターは，黒鉛製漏斗のスラグ流出孔 径 $(3.0 \sim 4.8 \mathrm{~mm})$ 扰よびスラグ塩基度 $\left(\mathrm{CaO} / \mathrm{SiO}_{2}=0.8\right.$, 1.2 の 2 水準) である. Table 1 に供試スラグの化学組 成を示寸。

実験では，スラグ流出孔に黒鉛製ストッパーを装着し た黒鉛製漏斗内にあらかじめ $50 \mathrm{~g}$ のスラグを入れ，電 気炉内で $\mathrm{Ar}$ 雲囲気のもと $1500^{\circ} \mathrm{C}$ まで加熱した。温度 が $1500^{\circ} \mathrm{C}$ に到達した後，ただちにストッパーを抜取っ てスラグを滴下させた，黒鉛製漏斗内にスラグが滞留し ていた場合は、炉冷後、漏斗からそのスラグを取り出して 拡大投影機を用いてスラグの寸法と接触角を測定した。

\section{$2 \cdot 2$ コークス充填層内での静的ホールドアップの測定}

Fig. 2 に滴下带シミュレータの概略を示す. 実験で は，二珪化モリブデンを発熱体とする竪型電気炉の均熱 带に, 粒径 11 13 mm のコークスを所定層高 $(50 \mathrm{~mm}$

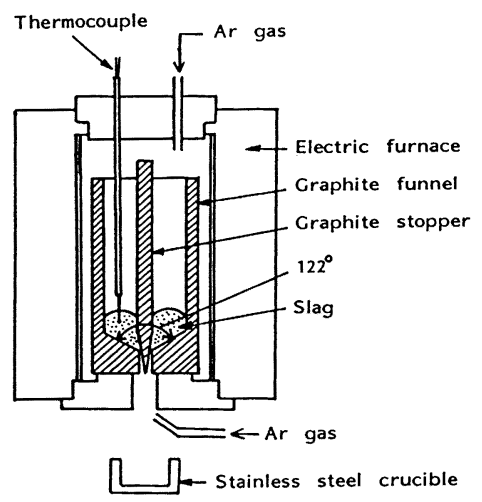

Fig. 1. Experimental apparatus for slag flow in quasi-packed bed.

Table 1. Chemical compositions of slags.

\begin{tabular}{|c|c|c|c|c|c|}
\hline \multirow{2}{*}{ Sample } & \multicolumn{4}{|c|}{ Chemical compositions (mass \%) } & \multirow{2}{*}{$\underset{(-)}{\mathrm{CaO} / \mathrm{SiO}_{2}}$} \\
\hline & $\mathrm{CaO}$ & $\mathrm{SiO}_{2}$ & $\mathrm{Al}_{2} \mathrm{O}_{3}$ & $\mathrm{MgO}$ & \\
\hline A & 44.3 & 36.9 & 12.8 & 6.1 & 1.2 \\
\hline B & 35.5 & 45.8 & 12.9 & 5.8 & 0.8 \\
\hline
\end{tabular}

と $80 \mathrm{~mm}$ の 2 水準) まで充填した黒鉛製るつぼ（内径 $60 \mathrm{~mm} \times$ 深さ $200 \mathrm{~mm}$, 底部に径 $5 \mathrm{~mm} \times 13$ 個のスラグ流 出孔）を設け，Ar 雲囲気中で所定温度まで昇温した。 所定温度に到達後は, 高炉滴下带におけるスラグの空塔 滴下速度と同等の条件 ${ }^{1)}\left((4.8 \pm 0.3) \times 10^{-5} \mathrm{~m} / \mathrm{s}\right)$ にな るようにるるつぼの上部からマイクロスクリューフィー ダーにより粒状スラグを連続的に供給した。コークス充 塡層内を滴下したスラグ融液は, 装置下部の荷重計上に 置かれたるつぼで捕集し，そのスラグの積算重量を連続 測定した。

実験時間はスラグ供給開始から $90 \mathrm{~min}$ であり，また， 供給時間は充填層内でのスラグの滴下が定常に達するま での時間を考慮して約 $13 \mathrm{~min}$ とした。

供試スラグは特級試薬の $\mathrm{CaO}, \mathrm{SiO}_{2}, \mathrm{Al}_{2} \mathrm{O}_{3}, \mathrm{MgO}$ を 用い，あらかじめ所定配合して焼成し， $0.25 \sim 1.0 \mathrm{~mm}$ の粒度に粉砕したものである. 焼成温度は各スラグ組成 での平衡液相線温度の $50 \sim 100^{\circ} \mathrm{C}$ 以下を目安とし, 焼

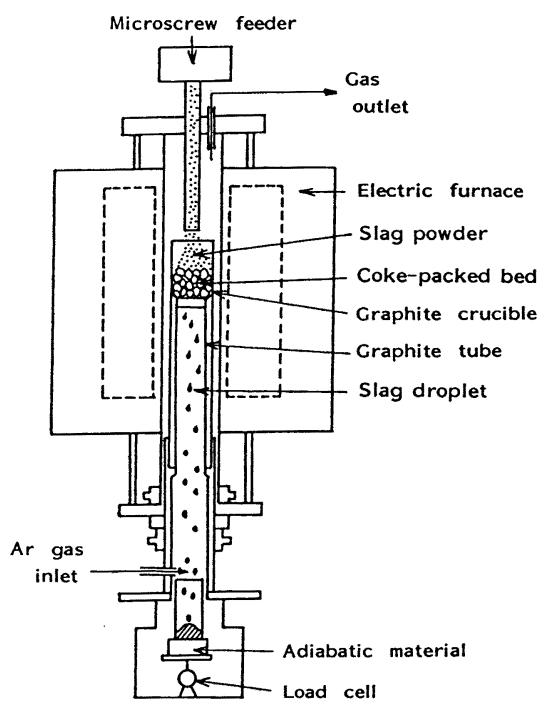

Fig. 2. Experimental apparatus for slag flow in coke-packed bed.

Table 2. Chemical compositions of slags after taking measurements of static holdup.

\begin{tabular}{c|ccccc|c}
\hline \multirow{2}{*}{ No. } & \multicolumn{5}{|c|}{ Chemical compositions (mass \%) } & \multirow{2}{*}{\begin{tabular}{c} 
CaO/ \\
\cline { 2 - 6 }
\end{tabular}} \\
\cline { 2 - 6 } & $\mathrm{CaO}$ & $\mathrm{SiO}_{2}$ & $\mathrm{Al}_{2} \mathrm{O}_{3}$ & $\mathrm{MgO}$ & $\mathrm{S}$ & \\
\hline 1 & 39.0 & 42.0 & 14.0 & 5.7 & 0.038 & 0.93 \\
2 & 33.9 & 43.1 & 14.6 & 5.8 & 0.039 & 0.79 \\
3 & 39.0 & 42.0 & 14.0 & 5.7 & 0.038 & 0.93 \\
4 & 40.8 & 39.8 & 13.7 & 6.4 & 0.088 & 1.03 \\
5 & 42.1 & 38.1 & 13.3 & 6.5 & 0.027 & 1.10 \\
6 & 44.0 & 36.0 & 13.5 & 6.5 & 0.031 & 1.22 \\
7 & 39.0 & 42.0 & 14.0 & 5.7 & 0.038 & 0.93 \\
8 & 42.9 & 37.5 & 13.1 & 6.9 & 0.017 & 1.14 \\
\hline
\end{tabular}


成状況を観察しながら温度を設定した。 Table 2 はホー ルドアップ実験での供試スラグの化学組成を示す.

るつほ底部の滴下孔等, 充填層以外の部分に滞留する スラグの影響を除くため, 充填層高を 2 水準変えた実験 を行い，(1) 式を用いて静的ホールドアップ $\left(h_{s}\right)$ を算 出した。なお，本研究で得られた $h_{s}$ とは Shulman ${ }^{5)}$ の 定義した，スラグの供給を止めて放置した後に充填層内 に滞留している融液の容積百分率である.

$$
h_{s}=100\left(W^{\prime}{ }_{80}-W^{\prime}{ }_{50}\right) /\left(\rho \cdot V_{30}\right) \cdots \cdots \cdots \cdots \cdots(1)^{5)}
$$

記号の説明は以下に用いるものを含め, 文末に一括した.

充填層の空隙率 $(\varepsilon)$ は実験ごとに実測のコークス層高, コークス粒子重量とコークスのみかけ密度から計算によ り求めた。 $\varepsilon は 0.45 \pm 0.01$ であった。

\section{$2 \cdot 3$ スラグの密度, 表面張力および黒鉛との接触角の 測定}

測定は静滴法によった. スラグ試料 $0.4 \sim 0.5 \mathrm{~g}$ を水 平な黑鉛基盤上に置き，電気炉内を排気して精製 $\mathrm{Ar} カ ゙$ スに置換後，Ar ガスを流しながら $1450 〜 1550^{\circ} \mathrm{C} に$ 昇 温してスラグ液滴の写真撮影を $5 \mathrm{~min}$ 閏隔で $240 \mathrm{~min}$

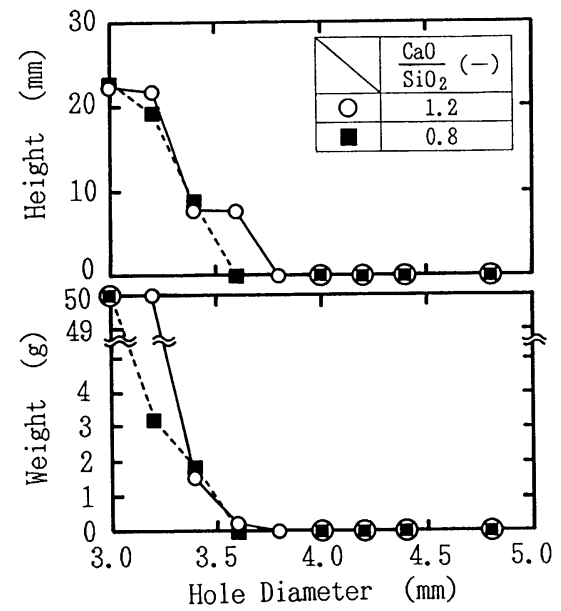

Fig. 3. Effect of hole diameter on dropping behavior of molten slags.

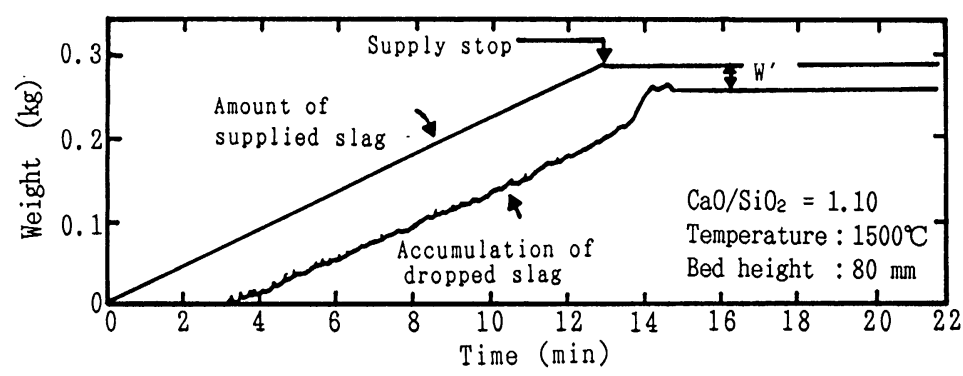

Fig. 4. An example of experimental result.
行った.この液滴形状をもとに, Bashforth-Adams の 数表6)を用いて接触角, 密度および表面張力を算出した. 本測定に供したスラグ試料は上述の静的ホールドアップ 測定実験でコークス充塡層内を滴下後，炉下部のるつほ で捕集したものである(Table 2).

なお，報告例 ${ }^{7) \sim 10)}$ の多い $\mathrm{CaO}-\mathrm{SiO}_{2}-\mathrm{Al}_{2} \mathrm{O}_{3}$ 系スラグ について表面張力の測定を行い, 本測定值の妥当性を事 前に確認した.

\section{3. 実 験 結 果}

\section{$3 \cdot 1$ 模擬充填層のスラグ流出孔径と滞留スラグ量との 関係}

Fig. 3 は黒鉛製漏斗のスラグ流出孔径と黒鉛製漏斗. 内の滞留スラグ重量, あるいは滞留スラグ高さとの関係 を示す．初期スラグ量が $50 \mathrm{~g}$ (スラグ液面高さ $22 \mathrm{~mm}$ ) の場合, 孔径 $3.2 \mathrm{~mm}$ 前後までは全くスラグの滴下はな いが，それ以上の孔径になると滴下し始めた。いったん 滴下すると, 漏斗内には $1 \sim 4 \mathrm{~g}$ とわずかなスラグしか 滞留せず，さらに孔径 $3.8 \mathrm{~mm}$ 以上ではスラグ融液の全 量が滴下した。なお， スラグ塩基度 $\left(\mathrm{CaO} / \mathrm{SiO}_{2}\right)$ が 1.2 と 0.8 のスラグの滴下状海には有意な差は認められ なかった.

漏斗内に滞留したスラグは, $\mathrm{CaO} / \mathrm{SiO}_{2}=1.2,0.8$ のいずれも黒鉛と濡れず，黒鉛表而の細孔の上に粒状の 形で残るものが大部分であった。

\section{$3 \cdot 2$ コークス充填層内の静的ホールドアップとスラグ の滞留状況}

Fig. 4 に測定結果の一例を示す。この例を含め測分 結果より（1)式を用いて算出した静的ホールドアップ $\left(h_{s}\right)$ とスラグ塩基度 $\left(\mathrm{CaO} / \mathrm{SiO}_{2}\right)$ の関係を Fig. 5 に 示す. $h_{s}$ は高塩基度側で高い值を示す傾问がみられた。 また， $\mathrm{CaO} / \mathrm{SiO}_{2}=0.93$ に打いて，温度が $1500^{\circ} \mathrm{C}$ と

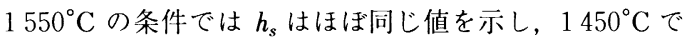
はこれらに比べて大きな值を示した。

Photo. 1 には, ホールドアップ実験後, 除冷した際 


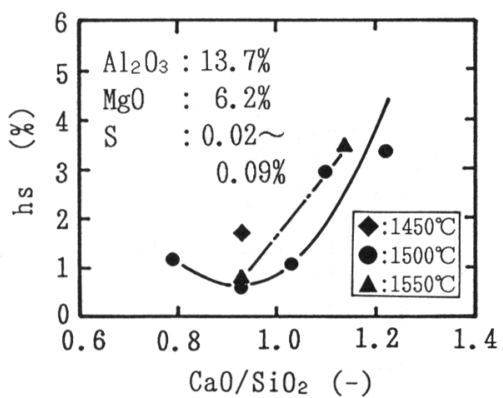

Fig. 5. Effect of slag basicity $\left(\mathrm{CaO} / \mathrm{SiO}_{2}\right)$ on static holdup $\left(h_{s}\right)$.

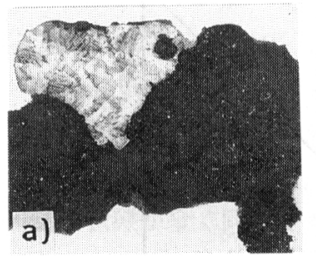

a) $\mathrm{Ca} 0 / \mathrm{SiO}_{2}=1.10$

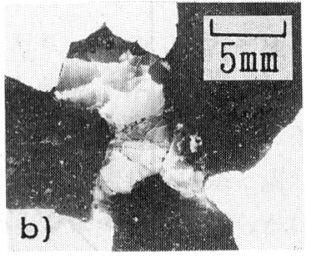

b) $\mathrm{CaO} / \mathrm{SiO}_{2}=0.79$
Experimental temperature : $1500^{\circ} \mathrm{C}$

Photo. 1. Residual states of slag droplet in coke-packed bed.

のコークス充填層へのスラグの滞留状況を示した。a） および b) は，それぞれスラグの塩基度が 1.10 および 0.79 の結果である。両者には,コークスへのスラグの 濡れ状況，ならびにコークス粒子間でのスラグの滞留状 況に相違点が認められる。 すなわち， $\mathrm{CaO} / \mathrm{SiO}_{2}=1.10$ のスラグ a)はコークスに濡れずに粒状となってコーク ス粒子間に保持された状態で滞留し, 一方, $\mathrm{CaO} / \mathrm{SiO}_{2}$ $=0.79$ のスラグ b)はコークスに濡れており，コークス 粒子の間隙に浸透する様相を呈していた。

\section{$3 \cdot 3$ ホールドアップ実験スラグの物性值測定結果}

Fig. 6 は，実験で用いたスラグの物性值を静滴法に 基づき黒鉛基盤上で測定した結果を示す。一部の測定例 を除くと, 測定温度に達してから $120 \mathrm{~min}$ 以降, 接触角 の変化は小さくほぼ定常状態になったので, 図中では接 触角を $120 \mathrm{~min}$ 以降の平均值で示した。

一般に, 高炉スラグの塩基度は 1.2 程度であるが, その組成におけるスラグと黒鉛の接触角は $140 \sim 160^{\circ}$ であり，ほとんど黒鉛に濡れなかった。

\section{4. 考察}

$4 \cdot 1$ 静的ホールドアップに関する従来研究結果との比 較

一般に，液体を固体に接触させると濡れの現象が起こ

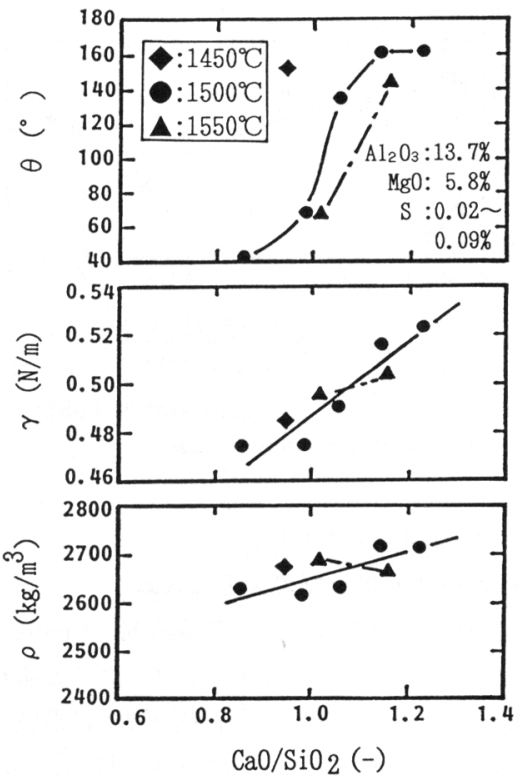

Fig. 6. Effect of slag basicity $\left(\mathrm{CaO} / \mathrm{SiO}_{2}\right)$ on $\operatorname{density}(\rho)$, surface tention $(\gamma)$ and contact angle $(\theta)$ of slags.

るが, 充填層内に打ける液の滞留現象もこの濡れによっ て生じたものと考えられる.濡れには（ｉ）浸漬濡れ，( ii ) 付着濡れと (iii)拡張濡れの 3 種類があり，それぞれに対 応する表面自由エネルギーの变化量として, 浸漬仕事 $\left(W_{I}\right)$ ，付着仕事 $\left(W_{A}\right)$ と拡張仕事 $\left(W_{S}\right)$ が定義され ている11).

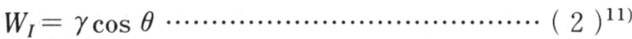

$$
\begin{aligned}
& W_{A}=\gamma(1+\cos \theta) \cdots \cdots \cdots \cdots \cdots \cdots \cdots \cdots \cdots \cdots \cdots \cdots \cdots \cdots \cdots \cdots(3)^{11)} \\
& W_{S}=\gamma(\cos \theta-1) \cdots \cdots \cdots \cdots \cdots \cdots \cdots \cdots \cdots \cdots \cdots \cdots \cdots \cdots \cdots(4)^{11)}
\end{aligned}
$$

高炉滴下带での静的ホールドアップ $\left(h_{s}\right)$ に関して, 福武ら ${ }^{1)}$ は融液の滞留が付着濡れによるものと考え, 滴 下液に作用する重力と固液界面での付着仕事との力の釣 合いより, 液の $h_{s}$ を( 5$)$ 式の修正キャピラリー数 $\left(C p_{m}\right)$ で整理している。

$$
C p_{m}=\rho g\left\{d_{p} \phi /(1-\varepsilon)\right\}^{2} /\{\gamma(1+\cos \theta)\} \cdots \cdots(5)^{1)}
$$

$2 \cdot 2$ の実験で得られた $h_{s}$ の測定值を，同実験に用い たスラグの物性值を( 6 )式に代入して算出した $C p_{m}$ で 整理した。その結果を Fig. 7 に示す。同図には福武ら の冷間模型実験 $\left(\gamma=0.024 \sim 0.089 \mathrm{~N} / \mathrm{m}, \theta=0 \sim 114^{\circ}\right)$ の結果 ${ }^{1)}$ を併せて示す。 スラグ融液では $C p_{m}$ の増加と とともに $h_{s}$ が増大し, 福武らの結果と逆の傾向を示し た。すなわち，本結果については付着仕事が小さいほど 充塡層内のスラグ滞留量が大きくなり，その傾向は福武 


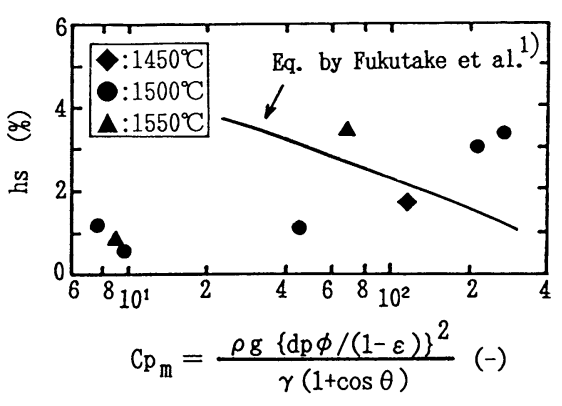

Fig. 7. Relationship between static holdup $\left(h_{s}\right)$ and modified capillary number $\left(C p_{m}\right)$.

らのモデルでは説明できない.

\section{$4 \cdot 2$ 静的ホールドアップのメカニズム}

コークス充填層内のスラグの滞留状況 (Photo. 1) に よれば，前述したように，スラグがコークスと濡れない 場合は粒状となってコークス粒子の間隙上に滞留し， 方, 需れる場合には間隙内に浸透する様相を呈していた。 よく知られた同様の現象に，液が毛細管の壁を濡らして 管内を上昇し，外部の液面より高くなったり，あるいは 液が管壁と濡れないために下降して外部の液面より低く なる現象がある．浸漬濡れに相当するこの現象は，毛管 現象と呼ばれており，濡れる場合と濡れない場合におけ る解析上の取扱いは同じである ${ }^{12)}$. したがって，スラ グの滞留は付着濡れではなく, 浸漬濡れによって生じる ものと考えられる.この考えの妥当性を検証するため, 黒鉛製漏斗を模擬充塡層としたスラグ滴下実験において 得られたデー夕をもとに以下の検討を試みた。

浸漬濡れの概念では，スラグが黒鉛と濡れない場合， そのスラグは自発的には細孔内に侵入しないと考えられ るが，孔径を大きくしたり，あるいは外部から压力を受 けるとスラグを細孔内に流入させることができる．2・1 における実験の場合，黑鉛製漏斗内のスラグ上面で受け る压力はスラグの静水压とスラグ-黒鉛界面の浸漬仕事 に伴う压力の和として生じたものである.したがって， 漏斗からのスラグの流出が停止Ｌ，Fig. 8 に示すよj な形状で漏斗内に滞留したスラグに作用する压力の釣合 いから（（6)式が成立するものと考えられる.

$$
\rho g h-\frac{\gamma_{\cos \theta_{2} \cos \alpha_{2}}}{\iota_{2} / 4}=-\frac{\gamma_{\cos } \theta_{1}}{\iota_{1} / 4}
$$

Fig. 9 は，実験での濡れ周辺断面の直径 $\left(\iota_{1}, \iota_{2}\right)$, ス ラグ-黒鉛界面での接触角 $\left(\theta_{1}, \theta_{2}\right)$ およびスラグと接し た位置での黒鉛の傾斜角 $\left(\alpha_{2}\right)$ の実測值を(6)式に代入 して算出した滞留スラグ高さ $\left(h_{\text {cal }}\right)$ と滞留スラグ高さ の実測值 $\left(h_{o b s}\right)$ の関係を示す。 $h_{o b s}$ と $h_{c a l}$ はよく一致

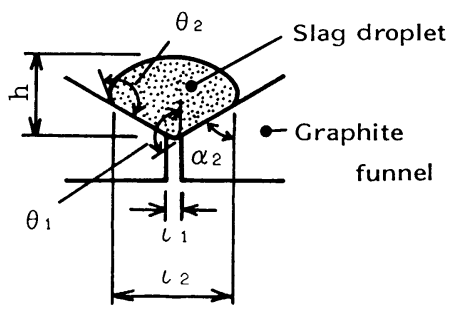

Fig. 8. State of slag droplet in graphite funnel.

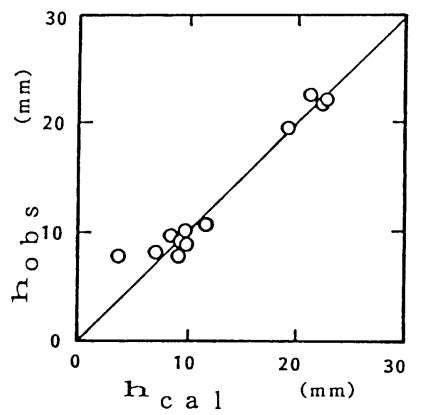

Fig. 9. Comparison of experimental values $\left(h_{\text {obs }}\right)$ with calculated values $\left(h_{\text {cal }}\right)$ by Eq. $(6)$.
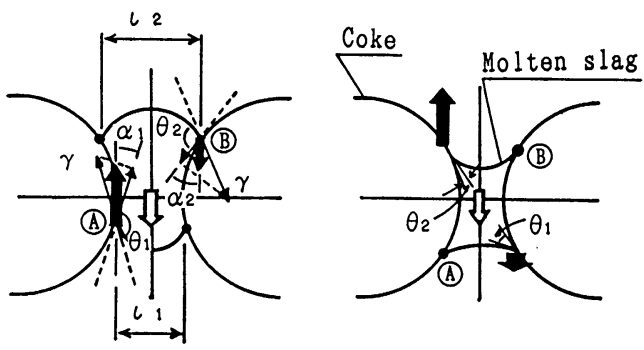

(a) Case of non-wet state (b) Case of wet state

Fig. 10. Model on capillarity for static holdup of slag droplets in coke-packed bed.

している. 同結果から，上述した浸漬濡れに基づくスラ グの滞留メカニズムの仮説が妥当であったものと考えら れる。

以上の予備検討の結果から, コークス允塡層内におけ るスラグ融液の滞留メカニズムは Fig. 10 に示したモデ ルに従うものと考えられる. スラグと接する充塡粒子表 層の形状が鼓のように中央がくびれた軸対称面であると 仮定すると，(6)式と同様，粒子閒に保持された融液に 作用する静水压と表面張力により生じた鉛㨁成分の力に 基づく压力との釣合いは，（７)式で示される. 


$$
\rho g h=-\frac{\gamma_{\cos } \theta_{1} \cos \alpha_{1}}{\iota_{1} / 4}+\frac{\gamma_{\cos } \theta_{2} \cos \alpha_{2}}{\iota_{2} / 4}
$$

しかしながら，本モデルを用いるに当たっては，(1)ス ラグがコークスと接した位置での傾き $\left(\alpha_{1}, \alpha_{2}\right)$ は一定 ではない, (2)黑鉛製漏斗内に滞留したスラグー黒鉛界面 の接触角 $\left(\theta_{1}, \theta_{2}\right)$ をそれぞれ測定した結果より明らか になったが，両者は異なった值を示しており，水平基盤 上で測定して得られる接触角 $(\theta)$ と異なる可能性がある, 等の問題がある. $\theta_{1}$ と $\theta_{2}$ に相違が生じた原因は，接触角 の履歴現象 (hysteresis) ${ }^{11)}$ に関係していると思われる.

本研究ならびに冷間模型実験1)の結果を併せて検討す ると, $h_{s}$ はほとんど需れない系 $\left(\theta>90^{\circ}\right.$ であり, $\left.W_{I} \ll 0\right)$ とよく濡れる系 $\left(\theta<90^{\circ}\right.$ であり, $\left.W_{I} \gg 0\right)$ の両極端の 条件で高い值となり, $\theta \simeq 90^{\circ}$ 前後 $\left(W_{I} \simeq 0\right)$ に極小値 を示す傾问があった。 なお， $(7$ ) 式右辺の第 1 項と第 2 項の相互関係が明確でなく，極度に濡れない系と濡れる 系の滞留状態が全く同じであるかについては明らかにで きなかった。

ここでは，便宜的に水平基盤上で測定した接触角を用 いるとともに，上述したような $h_{s}$ と $W_{I}$ の関係を反映 するために(8)式に示すように式の分母には絶対值を とった新たな修正キャピラリー数 $\left(C p_{m}{ }^{*}\right)$ を定義して $h_{s}$ を整理した。

$$
C p_{m}{ }^{*}=\rho g\left\{d_{p} \phi \varepsilon /(1-\varepsilon)\right\}^{2} /|\gamma \cos \theta|
$$

この式の中で系の代表長さとして, 充填層内水力学等価 平均㨁径 $d_{h}\left(=(2 / 3) d_{p} \phi \varepsilon /(1-\varepsilon)\right)^{13)}$ の比例定数を省 略したものを採用した。本実験に用いたコークスの形状 係数 $(\phi)$ は, 一田ら ${ }^{14)}$ が実測して得た均一径コークス の形状係数と空隙率の関係式をもとに $\phi=0.7$ とした. Fig. 11 に, 本研究データを福武らのデータ ${ }^{1)}$ と併せて 整理した結果を示す. 同四によれば, $h_{s}$ と $C p_{m}{ }^{*}$ の関 係は水などの溶液とスラグでは絶対值に違いがあるが, 両者とも同じ傾问を示しており， $h_{s}$ は $C p_{m}{ }^{*}$ で整理で きたといえる，本研究の実験条件の範井内では，以下の
実験式を得た。

$$
h_{s}=9.96\left(C p_{m}^{*}\right)^{-1.38}
$$

この推定式と実験值の相関係数は 0.86 である.

$h_{s}$ に関して杉山らの研究 ${ }^{2)}$ では, 液の粘度の効果を考 慮するために修正ガリレイ数 $\left(G a_{m}\right)^{1)}$ を含んだ推算式 を提示した. 本研究では, $h_{s}$ と $G a_{m}$ の相関がほとんど 認められなかったので， $h_{s} に$ によぼす液粘度の影響は 考慮しなかった.

\section{$4 \cdot 3$ 融液の静的ホールドアップにおよぼすコークス充 填層の空隙径の影響}

丹羽ら ${ }^{4)}$ の高炉での $h_{s}$ の測定結果では, コークスの 調和平均径 $\left(d_{p a}\right)$ が $20 \mathrm{~mm}$ を超えるとスラグの $h_{s}$ は 零になっている. 厳密にいえば, $h_{s}$ は $0.1 \sim 0.2 \%$ 程度 の值を示すが, これは, 高炉内に充填されたコークスの 凹凸部にスラグのプールが形成される等の理由によると 考えられる. 一方, 模擬充壃層でのスラグの滴下実験結 果（Fig. 3）では，いったん細孔内に流路が形成される と孔径 $3.8 \mathrm{~mm}$ 以上では, 同層内に滞留するスラグ量は 零となった. 両者の結果から, 浸漬濡れによってコーク ス層内に融液が滞留するには, スラグ組成が同一の場合, いいかえると， $\gamma$ が一定の場合に同層の空隙径がある値 以下であることが前提になるものと推察される.すなわ ち, その限界值以上では, コークスと濡れない融液は空 隙より流れ落ちるのみで $h_{s}$ は零に近い值を示し, 他方, 限界值以下では浸漬仕事による力で層内に融液が滞留す るものと考えられる. 次に, その限界空隙径に対応する コークス径を以下に検討する。

浸漬濡れの概念に従うと, 代表長さは液の単位断面当 たりの濡れ長さと等しい濡れ長さを持つ円筒の直径であ る. 充﨏層の空隙径は, それを構成する粒子径や形状と その配列状態に依存するため, この複雑な層の空隙径と して, 解析目的に沿って物理的意味のある代表径が選択 されており ${ }^{1)}$, この場合, 水力学等価平均直径 $\left(d_{h}\right)^{13)}$ を用いることが望ましいと考えられる，ただし，充填層

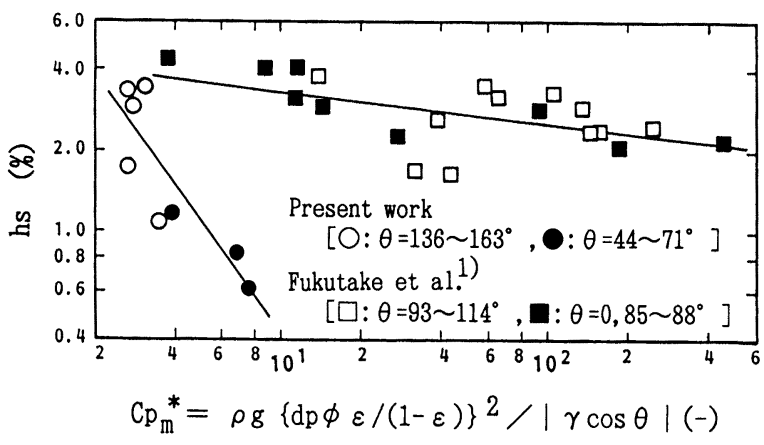

Fig. 11. Relationship between static holdup $\left(h_{s}\right)$ and modified capillary number $\left(C p_{m}{ }^{*}\right)$. 
内での液の滞留は, 液の流路となる空陌内で最もくびれ た部分, すなわち, 流路の最小断面部の直径 $\left(d_{\iota}\right)$ に影 響を受け，充填層内での流路の径を平均化した值に相当 する $d_{h}$ では正しく評価できないと推察される. そこで, 以後の解析は次の仮定を設ける. すなわち, 均一な直径 の球から成る単純立方格子と最密格子の $\varepsilon$, ならびに, その配列に基づく充壃層内における流路の $d$ ををもとに, $d_{\iota}$ と $d_{h}$ の関係には, これらの充填条件の中間をとり, (12)式が成立すると仮定する.

単純立方充填層 $; d_{\iota} / d_{h}=(\sqrt{2}-1) / 0.606 \cdots \cdots(10)$

最密充壃層 $; d_{l} / d_{h}=\{(2 / 3) \sqrt{3}-1\} / 0.234 \cdots(11)$

(10)式と (11) 式の定数を平均すると,

$$
d_{\iota} \fallingdotseq 0.67 d_{h}
$$

また, 模擬充填層の細孔径は高炉充填層内の $d$ に対応 すると仮定する。

高炉の炉芯コークス層で $\phi=0.65, \varepsilon=0.40$ の場合, (12)式に代入すると $d_{p} \fallingdotseq d_{t} / 0.194$ であるから，模擬充 填層の実験結果より, スラグがコークス層内で滞留し得 る限界コークス径は約 $20 \mathrm{~mm}$ と見積もられる. その值 は，丹羽ら ${ }^{4)}$ の結果とほぼ一致している。 また，スラグ の接触角 ${ }^{15) 16)}$ が $120^{\circ}$ 一定と仮定し, 炉芯コークスの $d_{p a}$ が $20 \mathrm{~mm}$ とすると, (9) 式から得られるスラグの $h_{s}$ の推算值は $0.6 \%$ と小さい値になる.

以上の結果より, 炉芯コークスの $d_{p a} 20 \mathrm{~mm}$ を境に, 上述したようにコークス層内でのスラグの滞留挙動は異 なるものと考えられる.

\section{5. 結言}

高炉滴下带での融液の静的ホールドアップのメカニズ ム, 並びに静的に融液が滞留し得るコークスの限界粒径 を明らかにする為, 高炉系スラグを対象に模擬充壃層や 滴下带シミュレータで実験を行い，その結果を実測した 表面張力等の物性值を用いて解析し, 以下の知見を得た.

(1)コークス層内でスラグ融液が静的に滞留する場 合，その静的ホールドアップは，浸漬濡れによりスラグ に作用する力に支配されるものと考えられた。

( 2 )静的ホールドアップは融液に作用する静水圧と浸 漬仕事による圧力の釣合いを考慮した無次元数 $\left(C p_{m}{ }^{*}\right)$ で整理できた。

( 3 )浸漬仕事によりスラグがコークス層内に静的に滞 留するには, コークス層の空隙径が限界值以下であるこ とが前提になり，それ以上の空隙径になると，コークス に濡れないスラグの静的ホールドアップはほぼ零になる ものと考えられた。 その空隙径に対心するコークスの調 和平均径は約 $20 \mathrm{~mm}$ であると推定された。

\section{記号}

$C p_{m}$ : 福武らの提案した修正キャピラリー数 (一)

$C p_{m}{ }^{*}$ : 本研究で提案した修正キャピラリー数 (一)

$d_{h}$ : 充壃層内水力学等価平均直径 $(\mathrm{m})=(2 / 3) d_{p} \phi \varepsilon /(1-\varepsilon)$

$d_{\iota}:$ 流路の最小断面部の直径 $(\mathrm{m})$

$d_{p}:$ 粒子径 $(\mathrm{m})$

$d_{p a}:$ 粒子の調和平均径 $(\mathrm{m})$

$g:$ 重力加速度 $\left(\mathrm{m} / \mathrm{s}^{2}\right)$

$G a_{m}:$ 修正ガリレイ数 $($ 一)

$h:$ スラグの高さ $(\mathrm{m})$

$h_{s}:$ 液の静的ホールドアップ $(\%)$

$\iota:$ 濡れ周辺断面の直径 $(\mathrm{m})$

$V_{30}$ : 充填層高 $30 \mathrm{~mm}$ の空塔容積 $\left(\mathrm{m}^{3}\right)$

$W^{\prime}{ }_{80}, W^{\prime}{ }_{50}$ : 充填層高 $80 \mathrm{~mm}$ および $50 \mathrm{~mm}$ においてそ れぞれスラグの供給を止めた後，充填層内に滞留して いたスラグの質量 $(\mathrm{kg})$

$W_{A}:$ 付着仕事 $(\mathrm{N} / \mathrm{m})$

$W_{I}:$ 浸漬仕事 $(\mathrm{N} / \mathrm{m})$

$W_{S}:$ 拡張仕事 $(\mathrm{N} / \mathrm{m})$

$\alpha$ : 液が固体と接した位置における固体表面の傾斜角度 $\left({ }^{\circ}\right)$

$\gamma:$ 液の表面張力 $(\mathrm{N} / \mathrm{m})$

$\varepsilon:$ 充塡層の空隙率 $($ 一

$\theta:$ 固液界面での接触角 $\left(^{\circ}\right)$

$\rho:$ 液の密度 $\left(\mathrm{kg} / \mathrm{m}^{3}\right)$

$\theta:$ 粒子の形状係数 (一)

添え字 1 は下部に位置するスラグー黒鉛界面, 2 は上 部に位置するスラグー黒鉛界面を示す。

\section{文献}

1) 福武 剛, 岡部俠児: 学振 54委-No. 1443 (昭和 54 年 2 月)

2 ) 杉山 喬, 中川朝之, 芝家秀治, 小田 豊: 鉄と鋼, 73 (1987), p. 2044

3 ) 佐藤暁彦, 鈴木政則, 佐藤修治, 石井邦宜: 材料とプロ七 ᄌ, 4 (1991), p. 1056

4 ) 丹羽康大, 炭䆝隆志, 牧章, 長野誠規, 酒井 敦, 桜井雅昭: 鉄と鋼, 76 (1990), p. 337

5 ) H. L. Shulman, C. F. Ullrich, N. Walls and A. Z. Proulr: AIChE J., 1 (1955), p. 259

6 ) 加藤 誠: 高温におけるスラグおよびメタルの物性測定 (1987), p. 337 [コンパス社]

7 ) 荻野和巳, 末滝哲郎, 築田凌一, 足立 彰: 鉄と鋼, 52 (1966), p. 1427

8 ) R. E. Boni and G. Derge: J. Met., 8 (1956), p. 59

9 ) 向井楠宏, 石川友美: 日本金属学会誌, 45 (1981), p. 147

10）小野清雄, 郡司好韾, 荒木 透: 日本金属学会誌, 33 (1969), p. 299

11) 坂尾 弘, 向井楠宏: 鉄と鋼, 63 (1977), p. 513

12）渡辺信淳, 渡辺 晃, 玉井康勝: 表面および界面 (1981), p. 3 [共立出版]

13）柴田耕一朗, 清水正賢, 稲葉拍一, 高橋礼二郎, 八木順一郎: 鉄と鐝, 77 (1991), p. 236

14）一田守政, 磯崎洋一, 田村健二: 鉄と䤱, 77 (1991), p. 1561

15) 佐藤暁彦, 柏谷悦章, 石井邦宜: 材料とプロセス, 3 (1990), p. 1034

16) H. Towers: Trans. Brit. Ceram. Soc., 53 (1954), p. 180 